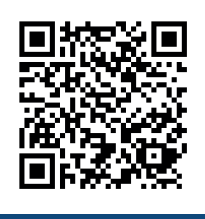

Maria Helena Fermino', Maristela Machado Araujo², Suelen Carpenedo Aimi², Felipe Turchetto², Álvaro Luís Pasquetti Berghetti², Thairini Claudino Zavistanovicz², Patrícia Mieth², Adriana Maria Griebeler², Juliana de Marques Vilella ${ }^{3}$

\title{
REUTILIZATION OF RESIDUES AS COMPONENTS OF SUBSTRATE FOR THE PRODUCTION OF Eucalyptus grandis SEEDLINGS
}

FERMINO, M. H.; ARAUJO, M. M.; AIMI, S. C.; TURCHETTO, F.; BERGHETTI, A. L. P.; ZAVISTANOVICZ, T. C.; MIETH, P.; GRIEBELER, A. M.; VILELLA, J. M. V. Reutilization of residues as components of substrate for the production of Eucalyptus grandis seedlings. CERNE, v. 24, n. 2, p. 80-89, 2018.

\section{HIGHLIGHTS}

Keywords:

Alternative substrates Carbonated rice husk Hydrolyzed rice husk Crushed peach kernel Forest nursery

Historic: Received | |/02/2018 Accepted 26/04/2018

+Correspondence: suaimi@gmail.com
The Eucalyptus grandis seedlings, presented quality when grown on organic substrates.

Organic compound mixed with carbonized and hydrolyzed rice husk and crushed peach kernel.

Carbonated rice husk (30\%), hydrolyzed rice husk (20\%) and crushed peach kernel (10\%).

These component can be used to improve the physical characteristics of the substrates.

\section{ABSTRACT}

Increased production of agro-industrial waste is a global concern, requiring proper disposal. In this sense, they can represent alternative sources for substrate production, adding value to the materials and reducing the cost of seedlings in the nursery. However, their proportions in the mixture should be adequate for better use of water and nutrients, ensuring better seedling quality. The objective of this study was to identify the potential of rice husk and peach kernel residue, as a secondary substrate component, for the production of Eucalyptus grandis seedlings. The carbonated ( $\mathrm{CRH})$, hydrolyzed $(\mathrm{HRH})$ rice husk and crushed peach kernel (CPK) were added at $0,10,20$ and $30 \%$ to an organic substrate. The results were submitted to analysis of variance and correlation analysis between the variables of the substrates and the morphological and physiological attributes. The results indicated that the $\mathrm{HRH}$ and CPK can add value to the agro-industrial residue when mixed to the organic compound in proportions of 20 and $10 \%$, respectively, being adequate and compatible with the use of $\mathrm{CRH}$ in the proportion of up to $30 \%$. Eucalyptus grandis seedlings, after 90 days of cultivation, presented quality to be hardened and dispatched when grown on organic compound substrates with up to $30 \% \mathrm{CRH}, 20 \% \mathrm{HRH}$ and $10 \% \mathrm{CPK}$.
' Department of Diagnostic and Agricultural Research/Rio Grande do Sul - Porto Alegre, Rio Grande do Sul, Brazil

${ }^{2}$ Federal University of Santa Maria - Santa Maria, Rio Grande do Sul, Brazil

${ }^{3}$ Department of Diagnostic and Agricultural Research/Rio Grande do Sul - Porto Alegre, Rio Grande do Sul, Brazil 


\section{INTRODUCTION}

Substrate is the physical support for the root growth of plants grown in containers, replacing the soil in situ. Alternative components in the formation of substrate, to produce seedlings in nurseries, are continuously tested in order to replace or improve existing ones. These components, when used in the substrate, should guarantee structural stability, allow gas exchange through the roots and provide water to the plants (Regan, 2014).

In the cultivation in containers, regardless of the substrate used, there is limitation of space for root expansion, so it is necessary that the medium be able to maintain a volume of water easily available to the plants, without compromising the oxygen concentration (Bunt, 196I). Other characteristics considered essential for the substrate are: having good structure and consistency, not contracting or expanding excessively with moisture variation, being free of toxic substances, inoculum of diseases, invasive plants, insects and excess salts, and being readily available (Kämpf, 2005).

The quality of the substrate determines the best use of factors, such as irrigation and nutrition, in addition to positively influencing the final product, making it possible to reduce or extend the time for seedling production. A substrate is generally the result of the blending of two or more components (materials) formulated and engineered to provide the desired physical and chemical properties. This is necessary because of the different species requirements, which conditions the use of various mixtures and proportions of the available components. Among the main components used by the industry are peat, vermiculite, perlite, decomposed tree bark, carbonated rice husk and coconut fiber. In this context, many agro-industrial residues can serve as an alternative material in the formation of substrates, allowing a more adequate disposal than conventional, adding value to materials and reducing the cost of seedlings in the nursery.

Rice (Oryza sativa) is a cereal of great consumption worldwide. Bonaguro et al. (2017) highlighted that rice husk is an agricultural by product that can be used in the composition of substrates. In southern Brazil, for example, it is estimated that approximately $20 \%$ of the total production of rice (around I.460 thousand tons) correspond to the husk fraction, which due to its high calorific value and low cost is mainly used for the generation of energy (Slabão, 2014).

In practice, after its use as a fuel for energy production, little use is made of the ash resulting from the process. According to Bezerra et al. (20I I) when rice husk ash is disposed in the environment, it can cause pollution because contains significant amount of residual carbon, and is also harmful to health due to the high silica content, which can cause "silicosis", a pulmonary infection.

However, the rice husk can also be used as a conditioner (secondary component), which is used to a lesser extent to improve the characteristics of the main component of the substrate. This component has been tested in the production of several plants, especially flowers, vegetables and seedlings of tree species (Rota; Pauletti, 2008; Kratz; Wendling, 20I6; Zavistanovicz et al., 2017; Watthier et al., 2017).

The characteristic that explains this use is the high aeration space, about $20 \%$ or more when used in the "carbonated" form, which contributes to make blends lighter and with a higher air-water ratio. Carbonization is an "incomplete burning" process, carried out in an artisan way, which allows the maintenance of the physical structure of the shell. On the other hand, an alternative way of using the rice husk is through its hydrolysis, whose treatment consists of immersing the bark in water, which is frequently replaced.

Among the agricultural activities that generate waste, we also mention the cultivation of peach (Prunus persica). In 2012, world production of peaches and nectarines was $21.083,15 \mathrm{I}$ tons, with China being the main producer, accounting for $57 \%$ of the total. Although Brazil is responsible for only I. $1 \%$ of the world production, the culture has important insertion in small family farms, destined for commercialization of fresh fruit and the canning industry (Protas; Madail, 2003).

As a residue of the peach canning industry, after extraction of the pulp, the kernel is obtained. There are, however, other applications such as the extraction of almond oil for the production of cosmetics (Voronetsky, $20 \mathrm{II}$ ), which depends on the process of specialized industrialization, unlike the use of crushed kernel in the mixture of substrates. This component, similarly to the carbonated or hydrolyzed rice husk, can be used to improve the physical characteristics of the substrates, concomitantly with cost reduction.

The genus Eucalyptus has been widely used in forest plantations due to its adaptation to different climatic conditions, soil and use of its products, thus reducing the pressure on native forests (Azevedo et al., 2017). For exotic forest species with strong commercial appeal, such as Eucalyptus, the production inputs, such as containers and commercial substrates, are well defined, but usually the latter are expensive and often geographically distant from production and, therefore, increasing the cost of the final product. 
Thus, additional studies are important to gain knowledge of the properties of new alternative materials and their possible mixtures (Kratz et al., 2013; Kratz; Wendling, 2013). The Eucalyptus grandis W. Hill ex Maiden. is a widely used species, including processed and solid wood and cellulose, consequently having its forestry known. Thus, morphophysiological attributes of the seedlings can be used as indicative in the qualification of inputs, as substrate.

In this sense, this research seeks to answer the following questions: a) are the hydrolyzed rice husk and the crushed peach kernel efficient components for seedling production of tree species? b) what are the appropriate proportion of carbonated, hydrolyzed rice husk and crushed peach kernel that can be used in the formation of a substrate for Eucalyptus grandis seedlings?

\section{MATERIAL AND METHODS}

The study was carried out at the Forestry and Forest Nursery Laboratory of the Department of Forest

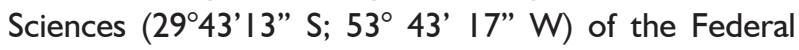
University of Santa Maria (UFSM) between October 2015 and January 2016. According to the Köppen's classification, the region has subtropical Cfa climate, with rainfall all year round, average annual rainfall between 1500 and $1600 \mathrm{~mm}$ and average annual temperature of $19.2^{\circ} \mathrm{C}$ (Matzenauer et al., 201 I).

The commercial substrate Beifort S-10B ${ }^{\circledR}$ (CS) was selected as the main component of the study because it is a stabilized organic substrate made from components derived from winemaking such as seeds and stalk, carbonated rice husk, peat and vermiculite. The components proposed as conditioners in this study were the rice husk in two preparation forms: carbonated $(\mathrm{CRH})$ and hydrolyzed or washed $(\mathrm{HRH})$ and crushed peach (CPK). To the mixtures of substrates, $8 \mathrm{~g} \cdot \mathrm{L}^{-1}$ of controlled release fertilizer and formula NPK 15-09-12 $+\mathrm{Ca}, \mathrm{Mg}+$ micronutrients (S, B, Cu, Mn, Fe and $\mathrm{Zn}$ ) were added.

The CRH was purchased from local producers. The HRH, alternative form proposed here, is based on the treatment applied to the tung shell (Aleurites sp.) and to the pecan nut (Carya illinoensis) according to Fermino et al. (2015) and was obtained using a water tank of $1000 \mathrm{~L}$, in which $500 \mathrm{~L}$ of rice husk and $500 \mathrm{~L}$ of water were placed. A sample was collected every two days in order to read the $\mathrm{pH}$ value and electrical conductivity. Subsequently, the water was completely drained, and the box filled with water (approximately $500 \mathrm{~L}$ ). This procedure was repeated until the $\mathrm{pH}$, the electrical conductivity (EC) and the sedimentation of the husk at the bottom of the vessel were stabilized, when the process was finished, after two weeks. The husk was then dried outdoors under a covered area, and then stored for use.

The peach kernel from the Company Oderich S.A. was used after drying and grinding in a hammer mill. To compose the mixtures, the $\mathrm{CRH}$, the $\mathrm{HRH}$ and the CPK were added in proportions of 10,20 and $30 \%$ (vol/vol) to the Beifort S- $10^{\circledast}$ commercial substrate (CS), totalizing 10 treatments (Table I). The experiment was carried out in a completely randomized design, with four replications of 12 seedlings, totalizing 48 seedlings per treatment.

TABLE I Different types and proportions of components tested as substrates for Eucalyptus grandis production.

\begin{tabular}{ccc}
\hline Treatments & Components & Proportion v:v \\
\hline TI & CS & 100 \\
T2 & CS:CRH & $90: 10$ \\
T3 & CS:CRH & $80: 20$ \\
T4 & CS:CRH & $70: 30$ \\
T5 & CS:HRH & $90: 10$ \\
T6 & CS:HRH & $80: 20$ \\
T7 & CS:HRH & $70: 30$ \\
T8 & CS:CPK & $90: 10$ \\
T9 & CS:CPK & $80: 20$ \\
T10 & CS:CPK & $70: 30$ \\
\hline
\end{tabular}

Where: CS - Commercial Substrate; CRH - carbonated rice husk; $\mathrm{HRH}$ - hydrolyzed rice husk; CPK - crushed peach kernel.

The analyzes of the physical and chemical characteristics of the substrates were carried out in the Laboratory of Analysis of Substrates for Plants (LASPP), in the Department of Diagnosis and Agricultural Research (DDPA/SEAPI), in Porto Alegre, RS, Brazil. The commercial substrate and the mixtures with $\mathrm{CRH}, \mathrm{HRH}$ and $\mathrm{CPK}$, in all proportions used, were submitted to the determination of the wet (WD) and dry (DD) densities (Brazil, 2007; Brazil, 2008), total porosity (TP), aeration space $(A E)$, readily available water (RAW) and buffering water (BW) by means of water availability curves at the voltages of $0,10,50$ and $100 \mathrm{~cm}$ of water column height corresponding to voltages of $0,10,50$ and $100 \mathrm{hPa}$ (Brazil, 2007; Fermino, 20I4). As with the laboratory reading of $\mathrm{pH}$ and $\mathrm{EC}$ values in substrate suspensions: deionized water in the ratio of I: 5 (vol:vol) (Brasil, 2007).

With the pure commercial substrate and the mixtures (Table I) the $50 \mathrm{~cm}^{3}$ polypropylene conical tubes, accommodated in the trays, were filled. Eucalyptus grandis seeds were purchased from the Institute for Research and Forestry Studies, with two to three seeds being sown directly in the containers. The trays were then taken to the greenhouse for emergencies and monitored along with routine practices of the nursery, maintaining control 
of irrigation, temperature, relative humidity and possible infestations. When the seedlings presented two to three pairs of leaves they were submitted to thinning, leaving only one seedling per container. At sixty days after sowing, alternation was performed, when the seedlings started to occupy $50 \%$ of the trays. Irrigation was performed four times a day with a flow rate of $8 \mathrm{~mm} \cdot$ day $^{\prime}$ ).

The evaluation of the morphological and physiological variables was performed at 90 days after sowing, when the seedlings of one of the treatments had a mean height of 20 $\mathrm{cm}$ and stem diameter $\geq 2 \mathrm{~mm}$, an appropriate condition for expedition (Wendling; Dutra, 2010).

By the non-destructive method, the following morphological attributes were observed: height $(H)$, with the aid of a ruler $(\mathrm{cm})$; stem diameter (SD), with a digital caliper $(\mathrm{mm})$; determination of relative levels of chlorophyll $a$ and $b$ and the fluorescence of chlorophyll $a$.

Relative levels of chlorophyll $a$ and chlorophyll $b$ were obtained with a chlorophyll meter (ClorofiLOG, CF 1030, Falker Automação Agrícola, Brazil), in leaves of the middle third of the plant, which are also expressed in the Falker Chlorophyll Index (FCl). Chlorophyll $a$ fluorescence was performed with a JUNIOR-PAM modulated pulse fluorometer (Walz, Germany) between 8:00 and 10:00h. For the evaluations, the fourth expanded leave was kept in the dark, wrapped in aluminum foil, for 30 minutes. It was then subjected to the determination of the initial fluorescence $\left(F_{o}\right)$ and, subsequently, to a pulse of saturating light $\left(10.000 \mu \mathrm{mol} \mathrm{m}{ }^{-2} \cdot \mathrm{s}^{-1}\right)$ for $0.6 \mathrm{~s}$, determining the maximum fluorescence $\left(F_{m}\right)$, the maximum photochemical efficiency of PSII $\left(F_{v} \cdot\left(F_{m}\right)^{-1}\right)$, calculated by the variable fluorescence ratio $\left(\mathrm{F}_{\mathrm{v}}=\mathrm{F}_{\mathrm{m}}-\mathrm{F}_{\mathrm{o}}\right)$.

In the evaluation of $\mathrm{H}$ and $\mathrm{SD}$, eight seedlings were used in each replication. For relative levels of chlorophyll $a$ and $b$ three plants were used, and for chlorophyll $a$ fluorescence one plant was used in each replication.

For the destructive method, three seedlings were used in each replication to obtain the following variables: aerial dry mass (ADM), root dry mass (RDM), total dry mass (TDM) and leaf area (LA).

The aerial and root parts were separated, the roots were washed in water with the aid of sieves. For the quantification of LA, the leaves were distributed on A4 white paper, after being pressed by transparent glass and photographed with a SONY digital camera (model DSC-TI00), fixed at $18 \mathrm{~cm}$ height and I.4 zoom. Afterwards, the images were processed with the aid of Image J. analysis software.

To obtain the dry mass, the aerial and root parts were submitted to oven drying with air circulation at $65^{\circ} \mathrm{C}$ until constant weight. Afterwards, they were weighed in a precision digital scale $(0.00 \mathrm{I} \mathrm{g})$ to obtain $\mathrm{ADM}, \mathrm{RDM}$ and TDM.

In the statistical analysis, the assumptions of normality of residues and homogeneity of variances were verified, using the Shapiro-Wilk and Bartlett tests, respectively (at $5 \%$ probability). When these assumptions were not met, the variables were transformed by the BoxCox method. Subsequently, the data were submitted to analysis of variance and polynomial regression analysis at $5 \%$ probability of error. For the analyzes, the statistical program SISVAR (Ferreira, 20I4) was used. In addition, the Pearson correlation $(r)$ was performed at a $5 \%$ significance level between the substrate and seedling variables.

\section{RESULTS}

\section{Analysis of the substrate mixtures}

The dry density (DD), total porosity (TP), aeration space (AS), readily available water (RAW) and buffering water (BW), as well as the chemical variables $\mathrm{pH}$ and electrical conductivity (EC) are different $(\mathrm{p}<0.05)$, depending on the component and proportion used (Figure I, 2 and 3). The commercial substrate (TI) presented DD of $267 \mathrm{~kg} \cdot \mathrm{m}^{-3}$, whereas for the mixtures with $\mathrm{CRH}$ (carbonated rice husk) and $\mathrm{HRH}$ (hydrolyzed rice husk) this variable was moderately reduced as the respective percentages in the composition increased (Figure IA). Conversely, for the mixtures with CPK (crushed peach kernel), the DD grew linearly as the proportion of this conditioner in the blend increased.

The total porosity of the commercial substrate was of $0.77 \mathrm{~m}^{3} \cdot \mathrm{m}^{-3}$, while the mixtures with $\mathrm{CRH}$ increased linearly to the TP $\left(\mathrm{T} 4=0.8 \mathrm{~m}^{3} \cdot \mathrm{m}^{-3}\right)$ with the addition of this conditioner (Figure IB). The mixtures with $\mathrm{HRH}$ did not significantly change the value of the TP ( $T 7=0.78$ $\left.\mathrm{m}^{3} \cdot \mathrm{m}^{-3}\right)$. The mixtures with CPK decreased the TP as this component increased $\left(\mathrm{TIO}=0.71 \mathrm{~m}^{3} \cdot \mathrm{m}^{-3}\right)$.

The commercial substrate (TI) presented AS of $0.13 \mathrm{~m}^{3} \cdot \mathrm{m}^{-3}$ (Figure 2A). Here was a linear increase of the AS in all the mixtures, that is, of the macroporosity with the increase of the conditioners. The values of this variable for the $\mathrm{CRH}$ and the CPK were equivalent, that is, they grew with the increase in percentages and presented similar values (T4 and TIO $=0.22 \mathrm{~m}^{3} \cdot \mathrm{m}^{-3}$ ). The HRH presented higher AS values of $0.31 \mathrm{~m}^{3} \cdot \mathrm{m}^{-3}$ when $30 \%$ was used in the mixture (T7).

The value of RAW of TI was $0.23 \mathrm{~m}^{3} \cdot \mathrm{m}^{-3}$ (Figure $2 \mathrm{~B})$, whereas in the mixtures with $\mathrm{CRH}$ these values were higher than all the treatments and varied little with the increase of the $\mathrm{CRH}$ content in the mixtures ( $\mathrm{T} 4=0.24$ 


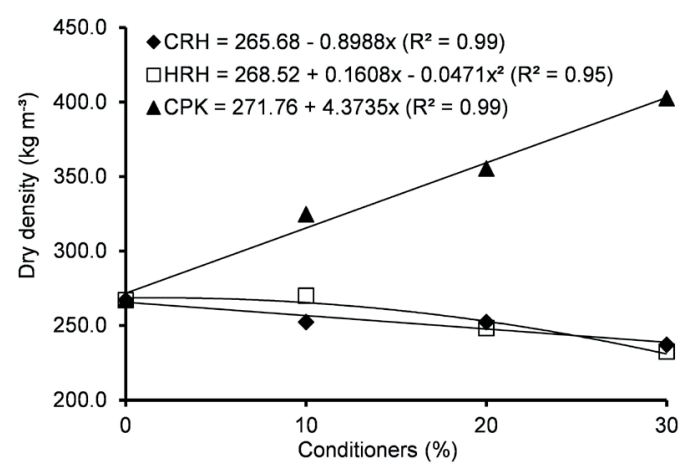

a.

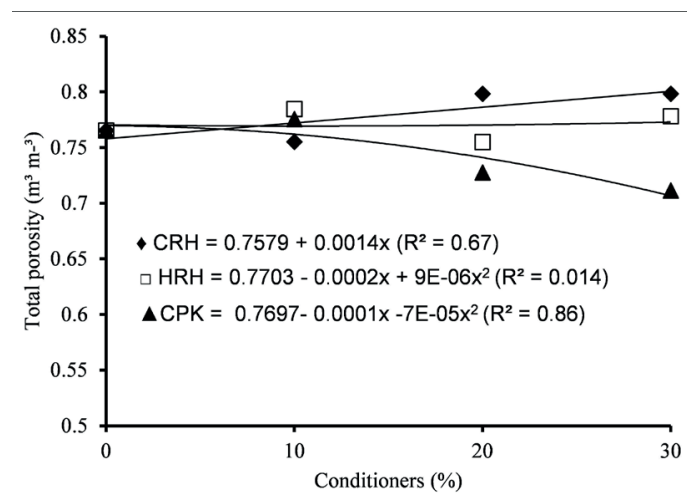

b.

FIGURE I a. Dry Density $\left(\mathrm{kg} \cdot \mathrm{m}^{-3}\right)$; b. Total Porosity $\left(\mathrm{m}^{3} \cdot \mathrm{m}^{-3}\right)$ commercial substrate mixtures and doses $(0,10,20$ and $30 \%$ ) of conditioners ( $\mathrm{CRH})$, hydrolyzed rice husk (HRH) and crushed peach kernel (CPK), Santa Maria, RS, Brazil.

$\left.\mathrm{m}^{3} \cdot \mathrm{m}^{-3}\right)$. The values for The mixtures with $\mathrm{HRH}$ and CPK reduced as the percentages of these components were increased $\left(\mathrm{T} 7\right.$ and TIO $\left.=0.170 .17 \mathrm{~m}^{3} \cdot \mathrm{m}^{-3}\right)$, except for the mixture of $10 \%$ of $\mathrm{HRH}$, which was similar to the $\mathrm{CRH}$.

The buffering water (BW) showed a trend of reduction regardless of the conditioner used (Figure $2 \mathrm{C})$. The values of the $\mathrm{CRH}$ were higher and with smaller amplitude than the ones of $\mathrm{HRH}$ and CPK, while the values of $\mathrm{HRH}$ were higher than those of CPK, at $10 \%$ and $20 \%$.

The value of the EC of the commercial substrate $\left(\mathrm{TI}=0.5 \mathrm{I} 35 \mathrm{dS} \mathrm{m}^{-1}\right)$ was higher than all mixtures, except for the use of $10 \%$ of HRH (T5 $\left.=0.538 \mathrm{dS} \mathrm{m}^{-1}\right)$. As the proportion of all conditioners increased, the values of the EC decreased (Figure 3A).

The $\mathrm{pH}$ value of the $\mathrm{CRH}$ mixtures was higher in comparison to all the others (Figure 3B). The mixtures with $\mathrm{HRH}$ and $\mathrm{CPK}$ presented lower values, even lower than the commercial substrate $(\mathrm{TI}=5.68)$. However, the difference between the lowest (T5 = 5.4I) and the highest $(\mathrm{T} 2=5.95)$ was very small.

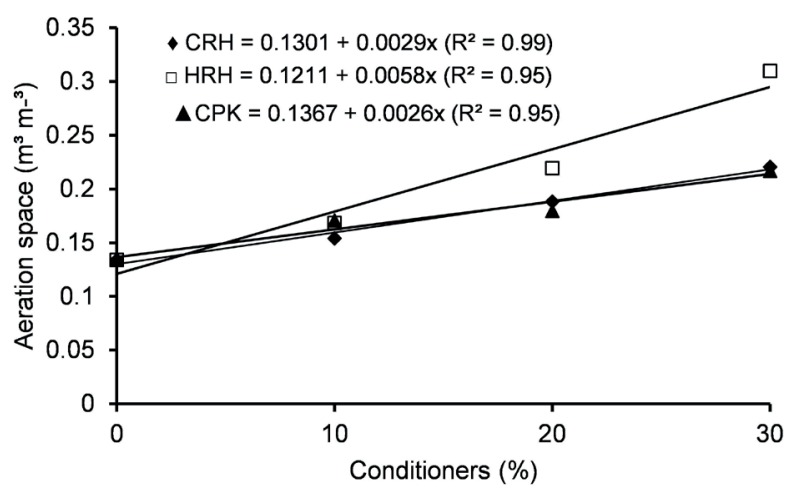

a.

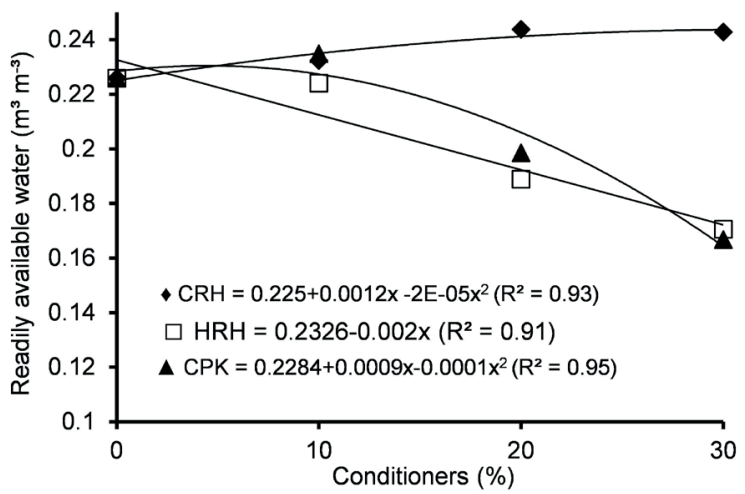

b.

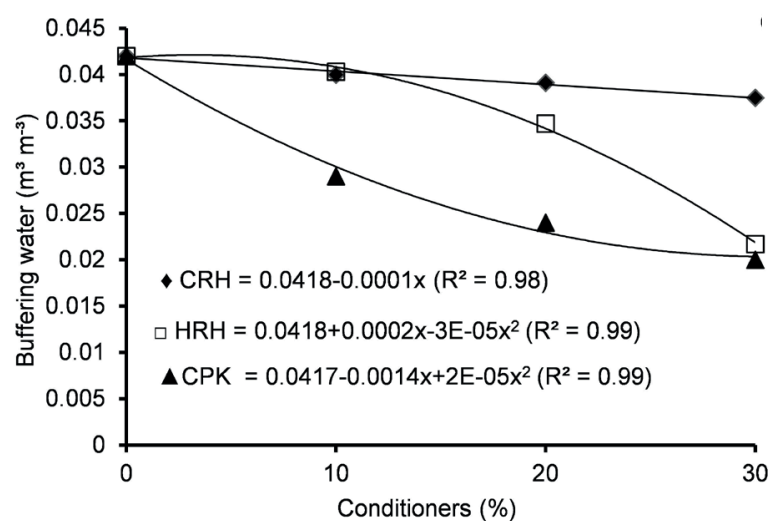

c.

FIGURE 2 a. Aeration Space $\left(\mathrm{m}^{3} \cdot \mathrm{m}^{-3}\right)$; c. Readily Available Water $\left(\mathrm{m}^{3} \cdot \mathrm{m}^{-3}\right)$; c. Buffering Water $\left(\mathrm{m}^{3} \cdot \mathrm{m}^{3}\right)$ from the mixtures of the commercial substrate and doses $(0,10,20$ and $30 \%)$ of conditioners [carbonated rice husk $(\mathrm{CRH})$, hydrolyzed rice husk $(\mathrm{HRH})$ and crushed peach kernel (CPK)], Santa Maria, RS, Brazil.

\section{Production of Eucalyptus grandis seedlings}

For height $(\mathrm{H})$, stem diameter $(\mathrm{SD})$ and root dry mass (RDM), there was no significant statistical difference $(p \leq 0.05)$ at 90 days of cultivation. The height of the $E$. grandis seedlings reached a mean value of $29 \mathrm{~cm}$, while the average of the stem diameter was $2.1 \mathrm{~mm}$ and that of the RDM reached $0.56 \mathrm{~g}$. For these three variables the CPK presented the lowest values, while the $\mathrm{CRH}$ presented the highest. 


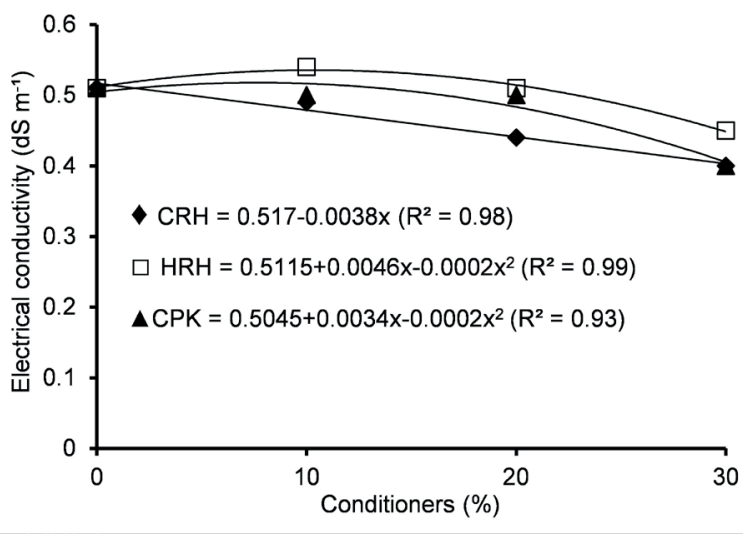

a.

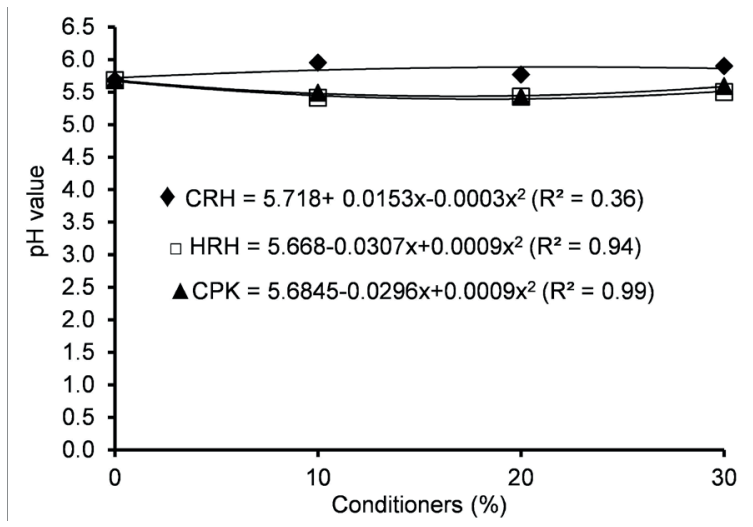

b.

FIGURE 3 a. Electrical conductivity $\left(\mathrm{dS} \cdot \mathrm{m}^{-1}\right)$; b. $\mathrm{pH}$ value of the commercial substrate mixtures and doses $(0,10,20$ and $30 \%)$ of conditioners [carbonated Rice husk $(\mathrm{CRH})$, hydrolyzed rice husk $(\mathrm{HRH})$ e crushed peach kernel (CPK)], Santa Maria, RS, Brazil.

The aerial dry mass (ADM), total dry mass (TDM), leaf area (LA), relative chlorophyll $a(\mathrm{Chl} a)$, chlorophyll $b(\mathrm{Chl} b)$, and maximum quantum yield of photosystem II $\left(F_{v}\left(F_{m}\right)^{-1}\right)$ were influenced by the substrate $(p<0.05)$.

The $E$. grandis seedlings presented higher ADM, TDM and LA (Figure 4) when the conditioner was the $\mathrm{CRH}$ or the $\mathrm{HRH}$, up to $20 \%$, when compared with the commercial substrate $\left(\mathrm{TI}=1.16 \mathrm{~g}, 1.67 \mathrm{~g}\right.$ and $13.10 \mathrm{~cm}^{2}$, respectively). For the attributes, the less favorable results were found in seedlings produced with substrate containing the $\operatorname{CPK}(T 9=0.73 \mathrm{~g}, \mathrm{I} .14 \mathrm{~g}$ and $\mathrm{T} 8=9.8 \mathrm{I} \mathrm{cm}$, respectively).

The FCl (Falker Chlorophyll Index) for $\mathrm{Chl} a$ and $C h l b$ of the $E$. grandis seedlings presented the same trend (Figure 5), respectively, with $36.0 \mathrm{I}$ and 10.23 as was observed in the commercial substrate (TI), similar to those obtained with up to $20 \%$ of the CRH (T3 = 36.04 and $10.23 \mathrm{FCl}$ ). For the $\mathrm{CPK}$ and the $\mathrm{HRH}$, the values decreased significantly after the addition of $10 \%$, but reversed the trend of the curve with the addition of $30 \%$ of the components (Figure 5 ).

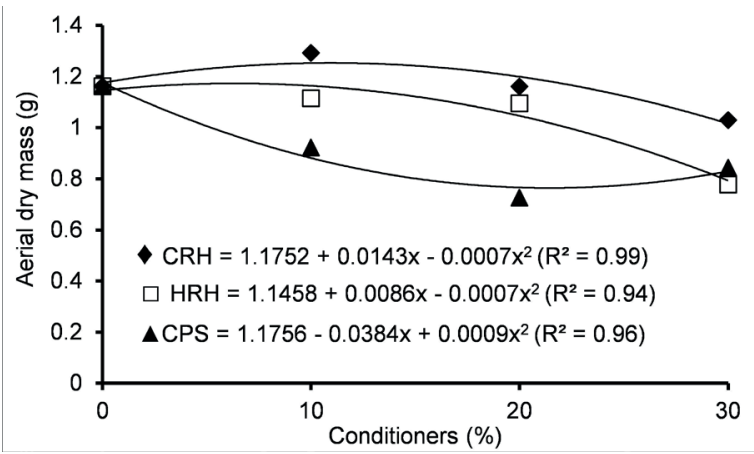

a.

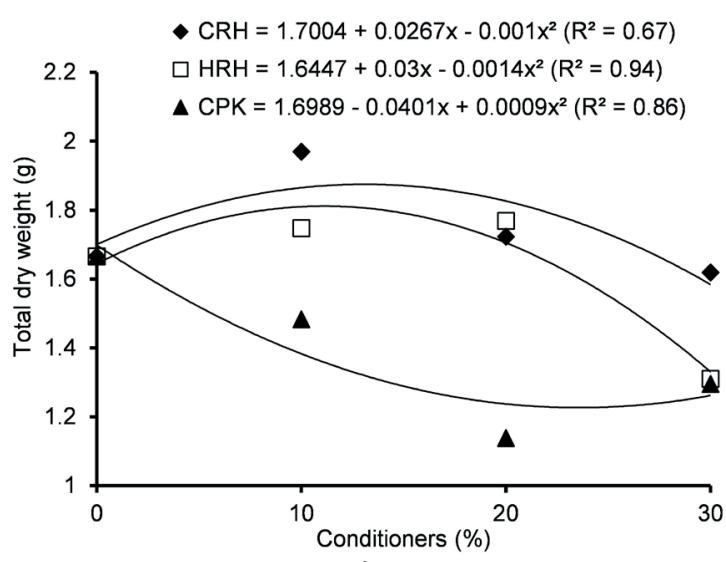

b.

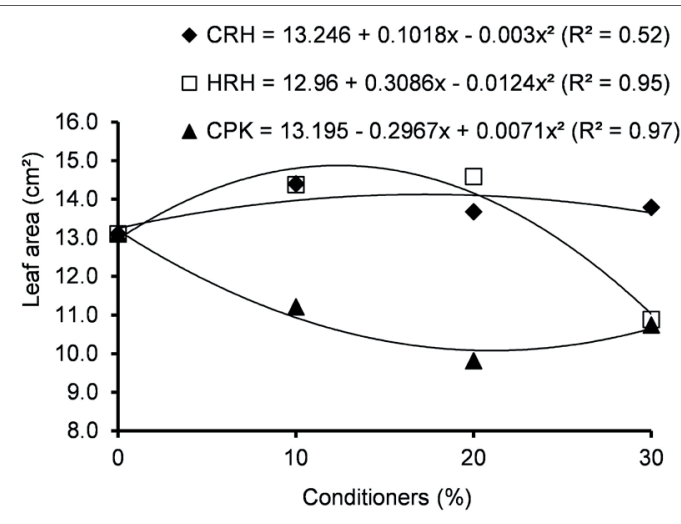

C.

FIGURE 4 a. Electrical conductivity $\left(\mathrm{dS} \cdot \mathrm{m}^{-1}\right)$; b. $\mathrm{pH}$ value of the commercial substrate mixtures and doses $(0$, 10, 20 and $30 \%$ ) of conditioners [carbonated Rice husk $(\mathrm{CRH})$, hydrolyzed rice husk $(\mathrm{HRH})$ e crushed peach kernel (CPK)], Santa Maria, RS, Brazil.

The maximum quantum yield of photosystem II $\left(\mathrm{F}_{\mathrm{v}}\right.$. $\left.\left(F_{m}\right)^{-1}\right)$ demonstrated a superior result when the conditioner was $\mathrm{HRH}$, in the proportion of $20 \%$ (T6 = $0.8 \mathrm{I}$ ), but seedlings produced with up to $30 \%$ of $\mathrm{CRH}$ and up to $10 \%$ of CPK presented adequate quantum yield of about 0.75 (Figure 6).

The DD correlated negatively with the TP, a result that confirms those observed in Figures IA and IB, as the DD increases, especially with the CPK, the TP decreases (Table 2). The same happens with $H, S D, R D M$, TDM, 


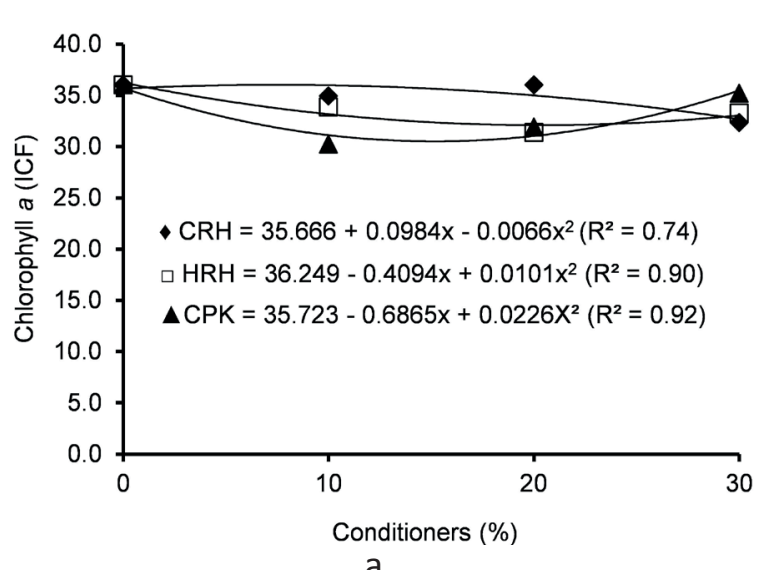

a.

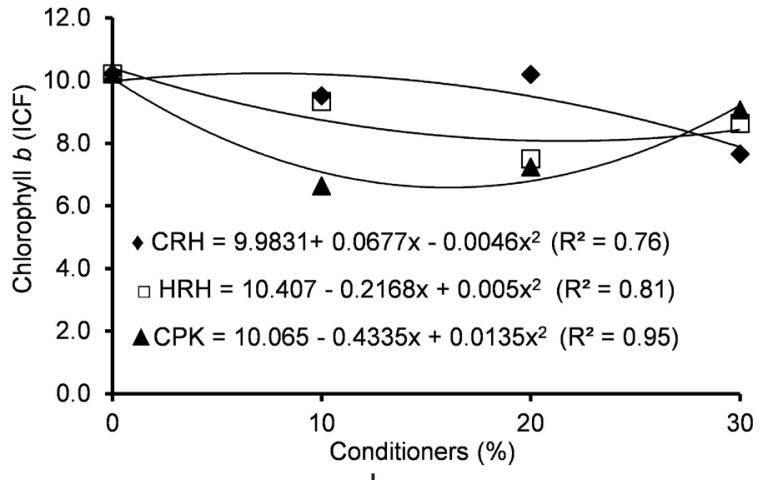

b.

FIGURE 5 a. Relative Chlorophyll a content (Chla); b. Relative Chlorophyll b content (Chlb) of Eucalyptus grandis due to the mixtures of commercial substrate and doses $(0,10,20$ and $30 \%)$ of conditioners conditioners [carbonated rice husk $(\mathrm{CRH})$, hydrolyzed rice husk $(\mathrm{HRH})$ e crushed peach kernel (CPK)], Santa Maria, RS, Brazil.

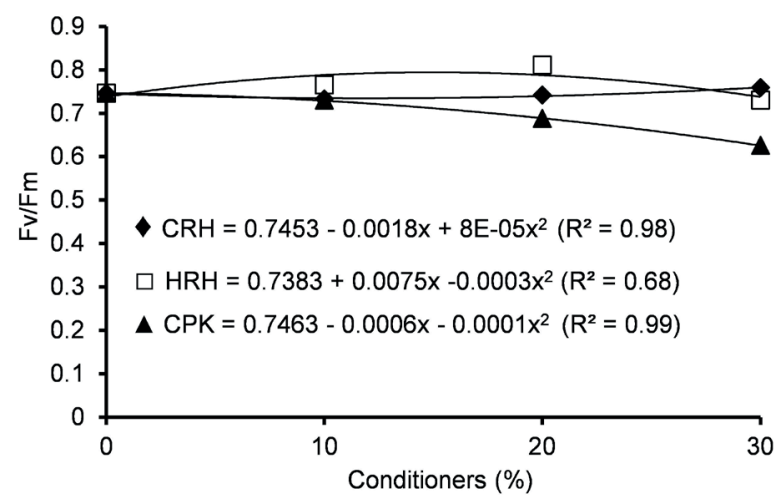

FIGURE 6 Maximum quantum yield of photosystem II (Fv. $\left.(\mathrm{Fm})^{-1}\right)$ of Eucalyptus grandis due to the mixtures of commercial substrate and doses $(0,10,20$ and 30 $\%)$ of conditioners [carbonated rice husk $(\mathrm{CRH})$, hydrolyzed rice husk $(\mathrm{HRH})$ e crushed peach kernel (CPK)], Santa Maria, RS, Brazil.

$\mathrm{LA}$ and $\mathrm{Fv} \cdot(\mathrm{Fm})^{-1}$ demonstrating that the addition of CPK in the mixture increases the DD and reduces the value of these morphophysiological attributes. The TP correlated positively with $\mathrm{H}$ and $\mathrm{Fv} \cdot(\mathrm{Fm})^{-1}$, so that the increase in the TP also increases in $\mathrm{H}$ and in the $\mathrm{Fv} \cdot(\mathrm{Fm})^{-1}$ ratio. The TP also presented a positive correlation with the RAW and this one with the BW and H, SD and MSPA. The BW correlated positively with $\mathrm{H}, \mathrm{SD}, \mathrm{ADM}, \mathrm{TDM}, \mathrm{LA}$ and $\mathrm{F}_{\mathrm{v}} \cdot\left(\mathrm{F}_{\mathrm{m}}\right)^{-1}$.

\section{DISCUSSION}

We found that the CPK (peach kernel) and CA (hydrolyzed rice husk) are potential components for the conditioning of substrates, similarly to the $\mathrm{CRH}$

TABLE 2 Correlation coefficients among the variables: dry density (DD), total porosity (TP), aeration space (AE), readily available water (RAW) and buffer water (BW), mixtures of commercial substrate and doses $(0,10,20$ e $30 \%)$ of conditioners [carbonated rice husk $(\mathrm{CRH})$, hydrolyzed rice husk $(\mathrm{HRH})$ e crushed peach kernel $(\mathrm{CPK})$ ], and the variables height $(H)$, stem diameter (SD), aerial dry mass (ADM), root dry mass (RDM), total dry mass (TDM), leaf aera (LA), Falker chlorophyll index $(\mathrm{FCl})$ clorophyll a and $\mathrm{b}$ and maximum photochemical efficiency of PSII (Fv/Fm) of Eucalyptus grandis at 90 days after sowing, Santa Maria, RS.

\begin{tabular}{|c|c|c|c|c|c|c|c|c|c|c|c|c|c|c|}
\hline & DD & TP & $\mathrm{AE}$ & RAW & BW & $\mathrm{H}$ & SD & ADM & RDM & TDM & LA & Chl $a$ & $\mathrm{Chl} b$ & $\mathrm{Fv} \cdot(\mathrm{Fm})^{-1}$ \\
\hline & I & - & - & - & - & - & - & - & - & - & - & - & - & - \\
\hline PT & $-0.78^{*} *$ & I & - & - & - & - & - & - & - & - & - & - & - & - \\
\hline $\mathrm{AE}$ & $-0.17^{\mathrm{ns}}$ & $0.07^{\text {ns }}$ & I & - & - & - & - & - & - & - & - & - & - & - \\
\hline RAW & $-0.40^{\mathrm{ns}}$ & $0.66 *$ & $-0.62^{\mathrm{ns}}$ & I & - & - & - & - & - & - & - & - & - & - \\
\hline BW & $-0.62^{\mathrm{ns}}$ & $0.57^{\mathrm{ns}}$ & $-0.6 I^{\text {ns }}$ & $0.79 * *$ & I & - & - & - & - & - & - & - & - & - \\
\hline $\mathrm{H}$ & $-0.69 *$ & $0.66 *$ & $-0.38^{n s}$ & 0.7I* & $0.86 * *$ & I & - & - & - & - & - & - & - & - \\
\hline SD & $-0.74^{*}$ & $0.62^{\mathrm{ns}}$ & $-0.44^{\mathrm{ns}}$ & $0.7 I^{*}$ & $0.95^{* *}$ & $0.92^{* * *}$ & I & - & - & - & - & - & - & - \\
\hline ADM & $-0.56^{\mathrm{ns}}$ & $0.4 I^{\mathrm{ns}}$ & $-0.55^{\text {ns }}$ & $0.64 *$ & $0.92 * *$ & $0.84 * *$ & $0.87^{* *}$ & I & - & - & - & - & - & - \\
\hline RDM & $-0.68^{*}$ & $0.49^{\text {ns }}$ & $-0.08^{n s}$ & $0.38^{\text {ns }}$ & $0.63^{\text {ns }}$ & $0.89^{*} *$ & $0.79 * *$ & $0.74^{*}$ & I & - & - & - & - & - \\
\hline TDM & $-0.64^{*}$ & $0.46^{\mathrm{ns}}$ & $-0.43^{n s}$ & $0.59^{\text {ns }}$ & $0.88 * *$ & $\left.0.9\right|^{* * *}$ & 0.90 *** & $0.97^{* * *}$ & $0.87^{* * *}$ & 1 & - & - & - & - \\
\hline LA & $-0.69 *$ & $0.52^{\mathrm{ns}}$ & $-0.30^{\text {ns }}$ & $0.53^{\mathrm{ns}}$ & $0.88 * *$ & $0.89 * *$ & $0.92 * *$ & 0.9 I*** & $0.86 * *$ & $0.95 * *$ & I & - & - & - \\
\hline Chl $a$ & $-0.09^{n s}$ & $-0.0 I^{n s}$ & $-0.23^{n s}$ & $0.08^{\text {ns }}$ & $0.33^{\mathrm{ns}}$ & $-0.03^{n s}$ & $0.16^{\mathrm{ns}}$ & $0.44^{\mathrm{ns}}$ & $-0.10^{\mathrm{ns}}$ & $0.29^{\text {ns }}$ & $0.24^{\text {ns }}$ & I & - & - \\
\hline Chl $b$ & $-0.25^{\mathrm{ns}}$ & $0.14^{\mathrm{ns}}$ & $-0.24^{\mathrm{ns}}$ & $0.14^{\mathrm{ns}}$ & $0.45^{\mathrm{ns}}$ & $0.14^{\text {ns }}$ & $0.32^{\mathrm{ns}}$ & $0.55^{\mathrm{ns}}$ & $0.07^{\mathrm{ns}}$ & $0.42^{\mathrm{ns}}$ & $0.38^{\text {ns }}$ & $0.97^{* * *}$ & I & - \\
\hline $\mathrm{Fv} / \mathrm{Fm}$ & $-0.83^{*} *$ & $0.66 *$ & $-0.05^{\mathrm{ns}}$ & $0.4 I^{\mathrm{ns}}$ & $0.67 *$ & $0.79 * *$ & $0.78 * *$ & $0.55^{\mathrm{ns}}$ & $0.76^{*}$ & $0.66 *$ & $0.75^{*}$ & $-0.26^{\mathrm{ns}}$ & $-0.06^{\mathrm{ns}}$ & 1 \\
\hline
\end{tabular}


(carbonated rice husk), but they should be used in different proportions. This can happen because aspects of the particles such as shape and size are different, consequently interfering in the arrangement of each mixture and in the porosity. This condition influenced the physical characteristics of the substrates, as it was possible to observe for the CPK, in which, the increase in the mixtures was directly related to the DD (dry density), and inversely related to the TP (total porosity), condition opposite to the $\mathrm{CRH}$ and $\mathrm{HRH}$ (Figure I).

The $\mathrm{CRH}$ is a component recognized for increasing the $A E$, in relation to the materials available in the market (Vieira; Pauletto, 2009; Faria et al., 2013; Kratz et al., 20I3; Watthier et al., 2017), and when added up to $30 \%$, showed the same behavior as CPK (Figure $2 \mathrm{~B})$, which highlights the peach kernel residue as potential to increase the aeration space, conditioning the drainage. On the other hand, when DD is observed, the use of the highest proportions of CPK are not suitable for containers

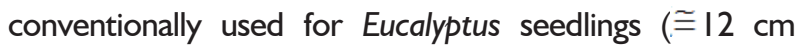
height), but for containers with a height between 20 and $30 \mathrm{~cm}$ (Kämpf, 2005). In addition, with an increase in the proportion of CPK, there was a significant reduction of the TP $\left(<0.8 \mathrm{~m}^{3} \cdot \mathrm{m}^{-3}\right)$, limiting its use.

The values of AS of the $\mathrm{HRH}$ are rarely found in materials used as components of substrates, which also makes it a material with high potential of use, with emphasis on the production of seedlings by cuttings that require more aeration space for rooting. This, combined with a reduction in the value of RAW (readily available water), when compared to $\mathrm{CRH}$, indicates the need to increase the frequency of irrigation due to the reduction of water availability, even in the face of a $20 \%$ increase in $\mathrm{HRH}$ (Figure 2B). This result may be useful for species with low water requirement due to adaptability to environmental conditions, such as Parapiptadenia rigida (Dutra et al., 20l6).

The values of BW (buffer water) between 0.02 and $0.05 \mathrm{~m}^{3} \cdot \mathrm{m}^{-3}$, are usually found for substrates in laboratory analyzes', being considered by Azevedo et al. (2014) as a content of little expressiveness to plants.

As expected by the characteristics of the secondary components (CPK, $\mathrm{HRH}$ and $\mathrm{CRH}$ ) EC values decreased with the addition of higher proportions of these materials (Figure 3A). However, the $\mathrm{pH}$ increased with the addition of $\mathrm{CRH}$, a predictable fact due to the high original value of $\mathrm{CRH}$, generally close to 8.0. On the other hand, for CPK and $\mathrm{HRH}$ there was a decrease in $\mathrm{pH}$ up to $20 \%$ of addition of the materials, subsequently increasing up to $30 \%$. In spite of these variations, for most mixtures $\mathrm{EC}$ and $\mathrm{pH}$ values may be considered suitable ( $E C \cong 0.48$ to $0.54 \mathrm{dS} \mathrm{m}^{-1}$ and $\mathrm{pH} \cong 5.5$ to 5.8) for plant growth, with a maximum limit of $0.75 \mathrm{dS} \mathrm{m} \mathrm{m}^{-1}$ for $\mathrm{EC}$ and a range between 5.5 and 6.3 for $\mathrm{pH}$ (Regan, 2014). However, the need for greater control when using $20 \%$ of $\mathrm{HRH}$ should be emphasized, since it can reach $\mathrm{pH}$ of 5.4 , requiring correction (Figure $3 \mathrm{~B}$ ).

Most of the mixtures favored the growth of Eucalyptus grandis, providing planting seedlings after 90 days of cultivation. The $\mathrm{CRH}$, in all proportions used, confirms other studies (Figuêredo et al., 20I4; Kratz; Wendling, 20l6). In the case of $\mathrm{HRH}$, which is obtained from a less polluting technique and with less social impact, adequate growth up to $20 \%$ in the mixture was found, similarly to the results obtained with the $\mathrm{CRH}$. This can be proved by the morphological attributes ADM, TDM and LA (Figure 4) and maximum quantum yield of photosystem II $\left(F_{v} \cdot\left(F_{m}\right)^{-1}\right)$, since $H, S D$ and RDM did not make it possible to distinguish superior quality between treatments. On the other hand, it is worth noting that in this study, the mean values of $H$ and SD are considered adequate for the production of seedlings of the genus Eucalyptus, since they are larger than $15 \mathrm{~cm}$ and $2 \mathrm{~mm}$, respectively (Wendling; Dutra, 2010).

The morphological attributes were superior to those observed in adequate treatments for Eucalyptus grandis seedlings, except for one of the studies whose SD was $2.2 \mathrm{~mm}$ (Nogueira et al., 20 I4; Silva et al., 20l4). Rossa et al. (2015), after six months of nursery seedling cultivation, despite the higher $\mathrm{H}(45 \mathrm{~cm})$ and SD $(2.4$ $\mathrm{mm}$ ), found values of ADM and TDM similar to the ones in this study, when $\mathrm{CRH}$ was used in up to $30 \%, \mathrm{HRH}$ in up to $20 \%$; while for the CPK (10\%) we observed close but lower values.

The results observed for the leaf area (Figure 4C) showed a trend similar to the ones of chlorophyll $a$ and $b$ (Figure 5), when using $\mathrm{CRH}$. However, the use of up to $20 \%$ of $\mathrm{HRH}$ allowed greater leaf area expansion, which compensated for the lower relative chlorophyll contents. On the other hand, for CPK, both attributes (leaf area and relative levels of chlorophyll) were unbalanced.

The values of $\mathrm{Chl} a$ and $\mathrm{Chl} b$ show that the seedlings produced in the substrates with different CPK ratios caused a relative limitation in water availability, provided by the lower values of RAW and BW, compared to $\mathrm{CRH}$ and $\mathrm{HRH}$. A similar result was observed in $E$. grandis seedlings produced in different water managements, where higher stress caused an increase in the chlorophyll content of plants (Silva et al., 2004; Arjenaki et al., 20I2). 
Despite this condition, seedlings produced with up to $10 \%$ CPK demonstrated adaptability, possibly due to the increased light uptake promoted by the leaf area, which also showed greater expansion when $\mathrm{CRH}$ or up to $20 \%$ of $\mathrm{HRH}$ was used (Figure $4 \mathrm{C}$ ). This trend was confirmed by the other morphological attributes and maximum quantum yield of photosystem II $\left(F_{\sqrt{ }} / F_{m}\right)$.

According to the $F / F_{m}$, which estimates the amount of carbon fixed based on the energy absorbed and whose recommended limit is 0.70 to 0.83 , under optimum conditions (Ritchie et al., 2010), it was possible to confirm that the best mixtures have up to $30 \%$ of $\mathrm{CRH}, 20 \%$ of $\mathrm{HRH}$ and $10 \%$ of CPK. Although the use of $30 \%$ of $\mathrm{HRH}$ still stays above 0.70 , a significant decline of the curve at $20 \%$ in the mixture can be observed, thus it can be interpreted that proportions higher than this may be inadequate.

We observed that, mainly ADM, TDM and LA were important attributes in substrate qualification, but we emphasize the maximum quantum yield of photosystem II $\left(\mathrm{F}_{\mathrm{v}} \cdot\left(\mathrm{F}_{\mathrm{m}}\right)^{-1}\right)$ as a powerful indicator in the present study, confirming Maxwell and Johnson (2000).

We emphasize that the highest correlation between the substrate physical variables in relation to the morphological and physiological attributes were DD and BW (Table 2). The DD (dry density) was inversely proportional to H, SD, RDM, TDM and LA. In the present study, the BW, normally regarded as having little influence to the plant, demonstrated a different behavior, showing a very strong correlation with $H, S D, A D M, R D M, T D M$, $L A$ and $F / F_{m}$. This, along with the adequate quality of the roots structure aggregated to substrate, with thin and clear roots in abundance, intermixed with the substrate (data not shown), makes it possible to consider that Eucalyptus grandis seedlings were efficient in absorbing water from the medium, including the small volume of BW 0.02 to $0.03 \mathrm{~m}^{3} \cdot \mathrm{m}^{-3}$ ).

The results indicate that the substrates considered to be of superior quality (CRH, $\mathrm{HRH}$ and CPK up to 30 , 20 and $10 \%$, respectively) for the growth of Eucalyptus grandis presented the following minimum and maximum values for physical and chemical characteristics: $D D=$ 240 to $320 \mathrm{Kg} \cdot \mathrm{m}^{-3}$; TP $=77$ to $80 \%$; AS $=16$ to $23 \%$; $\mathrm{RAW}=19$ to $24 \%$; $\mathrm{BW}=3.0$ to $4.1 \%$; $\mathrm{EC}=0.48$ to $0.54 \mathrm{dS} \cdot \mathrm{m}^{-1}$; and $\mathrm{pH}=5.5$ to 5.8 . In this condition, after 90 days of cultivation, Eucalyptus grandis seedlings reached minimum and maximum values $A D M=0.88$ to $1.25 \mathrm{~g}$; TDM $=1.39$ to $1.87 \mathrm{~g}$; $L A=10.9$ to $14.2 \mathrm{~cm}^{2}$; relative chlorophyll content $a$ and $b=32.1$ to 35.0 and 7.1 to $9.5 \mathrm{FCl}$, respectively; and maximum quantum yield of photosystem II $\left(F_{v} \cdot\left(F_{m}\right)^{-1}\right)=0.73$ to 0.77 .

\section{CONCLUSIONS}

The hydrolyzed rice husk and the crushed peach kernel can add value to the agro-industrial residue, when mixed to the organic compound in proportions of 20 and $10 \%$, respectively, being adequate and compatible with the use of carbonated rice husk in the proportion of up to $30 \%$.

The Eucalyptus grandis seedlings, after 90 days of cultivation, presented quality to be hardened and dispatched when grown on organic compound substrates with up to $30 \% \mathrm{CRH}, 20 \% \mathrm{HRH}$ and $10 \% \mathrm{CPK}$.

\section{ACKNOWLEDGMENTS}

The authors thank the FAPERGS for the PROBITI scholarship.

\section{REFERENCES}

ARJENAK, I. F. G.; JABBARI, R.; MORSHEDI, A. Evaluation of drought stress on relative water content, chlorophyll content and mineral elements of wheat (Triticum aestivum L.) varieties. International Journal of Agriculture and Crop Sciences, v. 4, n. II, p. 726-729, 2012.

AZEVEDO, G. B.; NOVAES, Q. S.; AZEVEDO, G. T. dos; SILVA, H. F.; ROCHA SOBRINHO, G. G. R.; NOVAES, A. B. Efeito de Trichoderma spp. no crescimento de mudas clonais de Eucalyptus camaldulensis. Scientia Forestalis, v. 45, n. II4, p. I-9, 2017.

BEZERRA, I. M. T.; SOUZA, J.; CARVALHO, J. B. Q. de; NEVES, G. A. Aplicação da cinza da casca do arroz em argamassas de assentamento. Revista Brasileira de Engenharia Agrícola e Ambiental, v. 15, n. 6, p. 639-645, 20 II.

BONAGURO, J. E.; COLETTO, L.; ZANIN, G. Environmental and agronomic performance of fresh rice hulls used as growing medium component for Cyclamen persicum L. pot plants. Journal of Cleaner Production, v. I42, n. 4, p. 2125-2132, 2017.

BRASIL. Instrução Normativa $n^{\circ}$ 17, de 21 de maio de 2007. Aprova os métodos analíticos oficiais para análise de substratos e condicionadores de solos, na forma do anexo a presente Instrução Normativa. Diário Oficial da República Federativa do Brasil União, Brasília, DF, Seção I, Página 8. Disponível em: <http://extranet. agricultura.gov.br/sislegis-consulta/consultarLegislacao. do >. Acesso em: 25 jun. 2017.

BRASIL. Instrução Normativa $n^{\circ} 31$, de 24 de outubro de 2008. Altera os subitens 3.1.2, 4.1 e 4.1.2, do Anexo à Instrução Normativa SDA n 17 , de 21 de maio de 2007. Diário Oficial da República Federativa do Brasil União, Brasília, DF, Seção I, Página 20. Disponível em: $<$ http://extranet.agricultura.gov.br/sislegis-consulta/ consultarLegislacao.do>. Acesso em: 25 jun. 2017.

BUNT, A. C. Some physical properties of pot-plant composts and their affect on plant growth. Plant and Soil, v. 12, n. 4, p. 322-332, 1961 . 
DUTRA, A. F.; ARAUJO, M. M.; TURCHETTO, F.; RORATO, D. G.; AIMI, S. C.; GOMES, D.R.; NISHIJIMA, T. Substrate and irrigation scheme on the growth of Parapiptadenia rigida (angico-vermelho) seedlings. Ciência Rural, v. 46, n. 6, p. $1007-1013,2016$.

FARIA, J. C. T.; CALDEIRA, A. M. V. W.; DELAMELINA, W. M.; GONÇALVES, E. de O. Uso de resíduos orgânicos no crescimento de mudas Mimosa setosa. Pesquisa Florestal Brasileira, v. 33, n. 76, p. 409-4I8, 2013.

FERMINO, M. H. Substratos, composição, caracterização e métodos de análise. Guaíba: Agrolivros, 2014. I I lp.

FERMINO, M. H.; TREVISAN, M.; BUSNELLO, A. C. Cascas de tungue e de noz pecan como alternativa de substrato para horticultura. Horticultura Brasileira, v. 33, n.4, p. 459-464, 2015.

FERREIRA, D. F. Sisvar: a Guide for its Bootstrap procedures in multiple comparisons. Ciência e Agrotecnologia, vol. 38, n.2, p. 109-II2, 2014.

FIGUÊREDO, K. S.; da SILVA, R. R.; DIAS, M. A. R.; de FREITAS, G. A.; RIBEIRO, M. M. C.; de MELO, A. V. Adição de casca de arroz carbonizada em diferentes substratos para produção de mudas de Eucalyptus globulus. Journal of Biotechnology and Biodiversity, v. 5, n, I, p. 7I-78, 2014.

KÄMPF, A. N. Produção Comercial de Plantas Ornamentais. Guaíba: Agropecuária, 2005. 254p.

KRATZ, D.; WENDLING, I. Produção de mudas de Eucalyptus dunnii em substratos renováveis. Revista Floresta, v. 43, n. I, p. I25-136, 2013.

KRATZ, D.; WENDLING, I.; NOGUEIRA, A. C.; SOUZA, P. V. de. Propriedades físicas e químicas de substratos renováveis. Revista Árvore, v. 37, n. 6, p. II03-1 I 13, 2013.

KRATZ, D.; WENDLING, I. Crescimento de mudas de Eucalyptus camaldulensis em substratos à base de casca de arroz carbonizada. Ceres, v. 63, n. 3, p. 348-354, 2016.

MAXWELL, K.; JOHNSON, G. N. Chlorophyll fluorescence-a practical guide. Journal of experimental botany, v. 5 I, p. 659-668, 2000.

MATZENAUER, R.; RADIN, B.; ALMEIDA, I. R. de. Atlas Climático: Rio Grande do Sul. Porto Alegre: Secretaria da Agricultura Pecuária e Agronegócio; Fundação Estadual de Pesquisa Agropecuária (FEPAGRO), $201 \mathrm{I}$.

NOGUEIRA, A. C.; SOUZA, P. G.; KRATZ, D.; BASSACO, M. V. M. Adding wood shavings to commercial substrates in the production of seedlings of Eucalyptus grandis Hill ex Maiden. Ambiência, v. 10, n. 2, p. 527-538, 2014.

PROTAS, J. F. da S.; MADAIL, J. C. M. Características econômicas e sociais da produção de pêssego no Rio Grande do Sul. In.: Sistema de Produção de Pêssego de Mesa na Região da Serra Gaúcha. Embrapa Uva e Vinho, Caxias do Sul. 2003. <https:// sistemasdeproducao.cnptia.embrapa.br/FontesHTML/ Pessego/PessegodeMesaRegiaoSerraGaucha/>
REGAN, R. P. Evaluating Alternative Growing Media Components. In: WILKINSON, K. M.; HAASE, D. L.; PINTO, J. R. Technical coordinators. National Proceedings: Forest and Conservation Nursery Associations, 2013. Fort Collins (CO): USDA Forest Service, Rocky Mountain Research Station. Proceedings RMRS-P-72. 50-53. 2014.

ROSSA, Ü. B.; ANGELO, A. C.; BOGNOLA, I. A.; WESTPHALEN, D. J.; MILANI, J. E. Fertilizante de liberação lenta no desenvolvimento de mudas de Eucalyptus grandis. Revista Floresta, v. 45, n. I, p. 85-96, 2015.

RITCHIE, G. A.; LANDIS, T. D.; DUMROESE, R. K.; HAASE, D. L. Assessing plant quality. Seedling Processing, Storage, and Outplanting. v. 7, Washington, DC: U.S. Department of Agriculture Forest Service 200. (Agric. Handbk. 674), 2010.

ROTA, L. D.; PAULETTI, G. F. Efeito da adição de casca de arroz em substrato comercial a base de turfa na produçao de mudas de Viola tricolor. Revista Brasileira Agrociência, v. I4, n. 3-4, p. 45-48, 2008.

SILVA, M. R.; KLAR, A.; PASSOS, J. R. Efeitos do manejo hídrico e da aplicação de potássio nas características morfofisiológicas de mudas de Eucalyptus grandis W (Hill ex. Maiden). Irriga, v. 9, n. I, p. 3 I-40, 2004.

SILVA, R. B. G. da; SILVA, M. R. da; SIMÕES, D. Substrates and controlled-release fertilizations on the quality of eucalyptus cuttings. Revista Brasileira de Engenharia Agrícola e Ambiental, v. I8, n. II, p. II24-I I29, 20 I4.

SLABAO, G.O.; LEDEMAR, C.V.; TIMM, L.C.; PAUL, D.L.; KATH, A.H. 20I4. Rice husk ash as corrective of soil acidity. Revista Brasileira de Ciências do Solo, v. 38, n. 3, p. 934-94I, 2014.

VIEIRA, M. A.; PAULETTO, E. A. Avaliação de atributos físicos do substrato de casca de arroz (Oryza sativa L.) carbonizada e tratada com polímeros hidrofílicos sintéticos. Bioscience Journal, v. 25, n. I, p. I-6, 2009.

VORONETSKY, O. L. E. G. Propriedades e aplicação de óleo de pêssego (2016). Disponível em: <http://pt.altarta.com/I0_23/ propriedades-e-aplicacao-de-oleo-de-pessego/>

WENDLING, I.; DUTRA, L.F. Produção de Mudas de eucalipto por sementes. In: WENDLING, I.; DUTRA, L. F. Produção de Mudas de eucalipto. Embrapa Florestas, 20 I0. P. I3-47.

WATTHIER, M.; SILVA, M. A. S.; SCHWENGBER, J. E.; FERMINO, M. H.; CUSTÓDIO, T. V. Production of lettuce seedlings in substrates with tung compost, carbonized rice husk and earthworm humus. Horticultura Brasileira, v. 35, n.2, p. I74- I79, 2017.

ZAVISTANOVICZ, T. C.; ARAUJO, M. M.; AIMI, S.C.; FLORES, R.; BERGHETTI, Á. L.; DEPONTI, G. Morphophysiological responses of Ilex paraguariensis seedlings to different substrates and fertilizations. Revista Brasileira de Engenharia Agrícola e Ambiental, v. 21, n. 2, p. II I-I I5, 2017. 